\title{
Pengaruh beberapa jenis pakan hijauan terhadap pertumbuhan ikan Koan Stenopharyngodon idella
}

\section{(The effect of different feed plants on growth of grass carp, Stenopharyngodon idella)}

\author{
Desmianti Babo*, Julius Sampekalo, dan Henneke Pangkey
}

\begin{abstract}
The aim of this research was to determine effect of feed plants on growth of grass carp, Stenopharyngodon idella. Grass carp used had an average length of $12.8 \mathrm{~cm}$ and weight of $21.00 \mathrm{~g}$. Fish were kept in 12 pouch nets with a density of 8 fish/net. Fish was fed in et libithum, twice a day. This research used Completely Randomized Design with four treatments: A Pennistum purpureum, B Eichornia crassipes, C Pistia stratiotes and D Azolla pinnata, each with three replications. Data from each treatment were statistically analyzed using analysis of variance and LSD. Research results showed that growth of fish in treatment C was significantly different as compared to other treatments. Length of fish reached 3.30 $\mathrm{cm}$, absolute growth $22.12 \mathrm{~g}$ and relative growth achieved $103.60 \%$. thus, application of feed plant Pistia stratiotes might improved growth of grass carp.
\end{abstract}

Keywords: grass carp, Stenopharyngodon idella, feed plants, growth

*Mahasiswa Pascasarjana UNSRAT, email: desmibabo@rocketmail.com

\section{PENDAHULUAN}

Pakan merupakan salah satu komponen penting dalam kegiatan budidaya ikan. Disatu sisi, pakan merupakan sumber materi dan energi untuk menopang kelangsungan hidup dan pertumbuhan ikan namun disisi lain pakan merupakan komponen terbesar (50\% $70 \%$ dari biaya produksi. Kian meningkatnya harga pakan ikan tanpa disertai kenaikan harga jual ikan hasil budidaya adalah permasalahan yang harus dihadapi setiap pembudidaya ikan. Oleh karena itu, upaya pencarian pakan alternatif yakni pakan alami yang murah serta mudah dijangkau terus dilakukan agar dapat mengurangi biaya produksi (Perius, 2011).

Ikan koan Stenopharyngodon idella adalah ikan introduksi yang merupakan salah satu jenis ikan ekonomis penting dalam budidaya perikanan air tawar di Indonesia. Ikan ini dikenal sebagai ikan herbivor yang rakus sehingga dijuluki sebagai "kambing air". Nama umumnya adalah grass carp atau ikan karper yang suka memakan rumput. Pada kondisi bahan makanan yang berkecukupan, ikan koan lebih memilih salah satu jenis pakan yang diminatinya saja (Kordi, 2009). 
Rumput gajah, eceng gondok, azolla dan kiapu merupakan jenis tumbuhan yang dapat tumbuh dengan subur, cepat dan terkadang mengakibatkan blooming pada daerah dan perairan tertentu, sehingga sebagian masyarakat menganggap tumbuhan tersebut merupakan gulma yang harus dibasmi karena bersifat merugikan. Eceng gondok, azolla dan kiapu yang banyak ditemui blooming di danau maupun areal budidaya, merupakan gulma perairan yang belum banyak dimanfaatkan dengan baik oleh masyarakat.

Pemanfaatan tumbuhan gulma dengan tingkat pertumbuhan yang cepat, mudah dijangkau oleh masyarakat serta berpotensi untuk dijadikan pakan ikan herbivor dikaitkan dengan penggunaan pakan alami sebagai pakan alternatif dalam pengembangan usaha budidaya ikan herbivor dalam hal ini yakni ikan koan. Oleh karena itu dalam penelitian ini dicobakan tumbuhan rumput gajah, eceng gondok, azolla dan kiapu sebagai pakan ikan koan/grass carp untuk mengetahui pengaruh pertumbuhan terhadap perlakuan dari keempat tanaman tersebut.

\section{BAHAN DAN METODE}

Penelitian ini dilaksanakan pada bulan November 2011 hingga bulan Januari 2012 di Balai Budidaya Air Tawar (BBAT) Tatelu, Minahasa Utara. Ikan uji yang digunakan adalah ikan koan (Stenopharyngodon idella) dengan rata-rata ukuran panjang 12,8 cm dan berat 21,00 gram sebanyak 96 ekor. Ikan tersebut merupakan benih dari induk ikan koan di BBAT Tatelu yang memijah pada bulan Februari 2011.

Pakan yang diberikan pada ikan uji sebagai perlakuan terdiri dari empat jenis tumbuhan hijau secara berturutturut perlakuan A,B,C dan D yakni menggunakan Pennistum purpureum (rumput gajah), Eichornia crassipes (eceng gondok), Azolla pinnata (azolla) dan Pistia stratiotes (kiapu). Keempat tumbuhan tersebut diambil dari BBAT Tatelu. Rumput gajah, eceng gondok dan kiapu yang digunakan, diambil daunnya yang segar dan masih muda, kemudian dipotong-potong dengan ukuran 2-5 mm. Sedangkan untuk azolla tidak dipotongpotong lagi karena sudah memiliki diameter yang relatif kecil, yakni $\leq 5$ $\mathrm{mm}$.

Ikan uji dipelihara dengan kepadatan 8 ekor pada setiap wadah. Ikan tersebut dipelihara selama 8 minggu dengan frekuensi pemberian pakan 2 kali sehari, yaitu pukul $06.00 \mathrm{~s} / \mathrm{d} 07.00$ dan $15.00 \mathrm{~s} / \mathrm{d} \quad 16.00$ dengan persentasi pemberian pakan secara et libithum yang dimulai dengan 5\% dari total berat tubuh pada masing-masing satuan uji. Sehari sebelum diadakan penimbangan ikan dipuasakan terlebih dahulu. ।

Pengumpulan data pertumbuhan panjang dan berat ikan dilakukan setiap dua minggu sekali dengan cara mengukur panjang dan menimbang berat satu persatu dari seluruh jumlah ikan yang ada pada setiap kantong jaring. Penyesuaian persentasi jumlah pakan dengan berat tubuh ikan dilakukan setiap dua minggu pada saat pengukuran ikan uji. Sedangkan pengukuran kualitas air, yakni suhu dan $\mathrm{pH}$ dilakukan seminggu sekali.

Parameter yang diukur pada penelitian ini adalah pertumbuhan, meliputi pertumbuhan panjang, pertumbuhan mutlak dan pertumbuhan nisbi. 
Pertumbuhan Panjang

Menggunakan

rumusan

pertumbuhan panjang menurut Effendie (1997); Helm dan Bourne (2004) dalam Rizal (2010), yakni:

$$
\mathrm{L}=\mathrm{L}_{\mathrm{t}}-\mathrm{L}_{0}
$$

Dimana L : Pertumbuhan panjang (cm)

Lt : Panjang akhir ikan (cm)

Lo : Panjang awal ikan (cm)

\section{Pertumbuhan Mutlak}

Menggunakan rumusan pertumbuhan mutlak menurut Effendie (1997); Helm dan Bourne (2004) dalam Rizal (2010), yakni:

$$
\Delta \mathrm{W}=\mathrm{Wt}-\mathrm{Wo}
$$

Dimana : $\quad \Delta \mathrm{W}$ : Pertumbuhan mutlak (gram)

$$
\begin{aligned}
& \text { Wt }: \text { Berat akhir (gram) } \\
& \text { Wo : Berat awal (gram) }
\end{aligned}
$$

\section{Pertumbuhan Nisbi}

Menggunakan rumusan pertumbuhan nisbi menurut Effendie (1997); Helm dan Bourne (2004) dalam Rizal (2010), yakni:

$$
\text { GR }\left(\%=\frac{W t-\text { Wo }}{W_{0}} \times 100\right.
$$

Dimana : GR (\%) : Pertumbuhan Nisbi Wt : Berat Akhir (g) Wo : Berat Awal (g)

Rancangan yang digunakan adalah Rancangan Acak Lengkap (RAL), dengan model matematis sebagai berikut
(Steel dan Torrie, 1981 dalam Kumean, 1997):

$$
\text { Yij }=\mu+\mathrm{Ti}+\sum
$$

Dimana Yij: Nilai pengamatan pada perlakuan ke-i dan ulangan ke-j $\mu$ : Nilai tengah Ti:Pengaruh perlakuan ke-i $\sum \mathrm{ij}$ : Komponen acak dari perlakuan ke-i dan ulangan ke-j

$$
\begin{array}{ll}
\mathrm{i} & : \text { Perlakuan } \\
\mathrm{j} & : \text { Ulangan }
\end{array}
$$

\section{HASIL DAN PEMBAHASAN}

Dari hasil yang diperoleh pada Gambar 1.a, rata-rata pertumbuhan panjang yang paling tinggi yaitu perlakuan C $(3,30 \mathrm{~cm})$, kemudian berturut-turut diikuti oleh perlakuan $\mathrm{B}$ $(0,76 \mathrm{~cm}), \mathrm{A}(0,66 \mathrm{~cm})$ dan D $(0,60 \mathrm{~cm})$. Dari hasil tersebut dapat dilihat bahwa pemberian pakan hijauan yang paling baik untuk pertumbuhan panjang ikan koan terdapat pada perlakuan C, yaitu perlakuan dengan pakan hijauan azolla.

Rata-rata pertumbuhan mutlak yang paling tinggi terdapat pada Perlakuan C $(22,12)$, kemudian berturutturut diikuti oleh perlakuan B $(3,55)$, A $(3,20)$ dan D $(1,64)$. Dari hasil tersebut dapat dilihat bahwa perlakuan $\mathrm{C}$ dengan pemberian pakan azolla memiliki nilai paling baik untuk pertumbuhan mutlak. Sedangkan pada Gambar c, memperlihatkan pertumbuhan nisbi ratarata hewan uji terbesar pada perlakuan $\mathrm{C}$ (103,60\%), diikuti oleh perlakuan B yaitu 16,90\%. Kemudian perlakuan A $(15,05 \%)$ dan terakhir perlakuan D $(7,16 \%)$. 
a

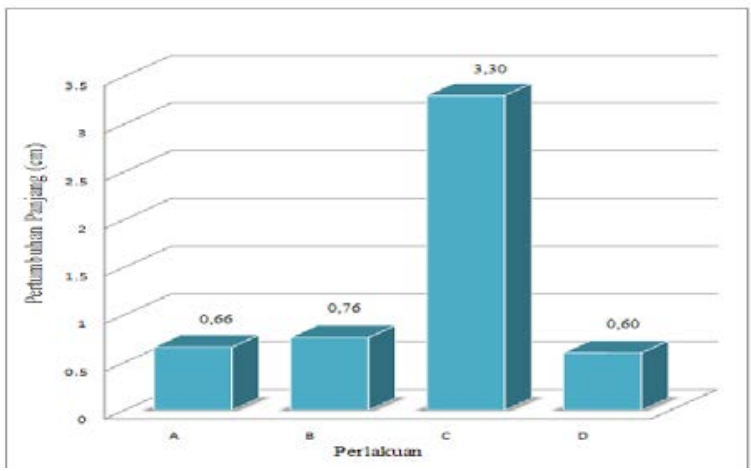

b

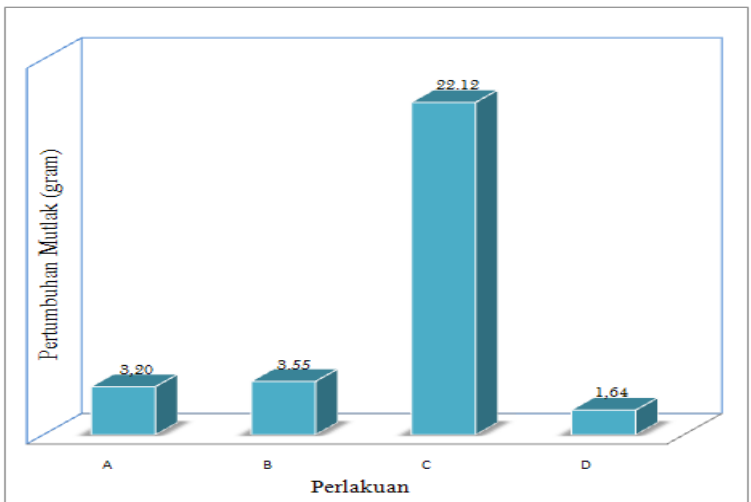

C

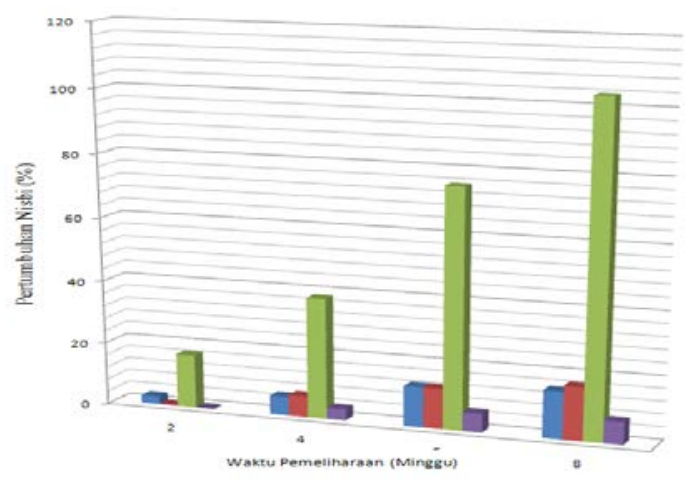

Gambar 1. Laju pertumbuhan ikan koan

(a) pertumbuhan panjang (cm),

(b) pertumbuhan mutlak (g)

(c) pertumbuhan nisbi (\%)

Berdasarkan hasil pengukuran panjang, berat dan analisis data menunjukan bahwa semua perlakuan memberikan respon terhadap pertumbuhan ikan koan, dimana hal ini dapat diartikan bahwa faktor-faktot penunjang pertumbuhan seperti pakan yang dicobakan serta pengukuran kualitas air yakni suhu dan $\mathrm{pH}$ yang diamati, telah berpengaruh pada ikan yang dicobakan. Namun dari percobaan tersebut dapat dilihat bahwa perlakuan C yakni dengan pemberian pakan azolla memberikan pertumbuhan yang paling baik dibandingkan dengan perberian pakan pada perlakuan A, B dan D.

Melihat pengaruh perlakuan yang sangat nyata mempengaruhi pertumbuhan yang ditujukan pada perlakuan $\mathrm{C}$ tersebut, dapat dikatakan bahwa, tingginya nutrisi yang dikandung di dalam pakan azolla, dapat mempengaruhi pertumbuhan dalam hal ini ukuran panjang dan berat ikan $S$. idella. Nutrisi yang terkandung dalam pakan hijauan azolla, pada perlakuan C, sangat jauh berbeda dibandingkan dengan pakan hijauan yang diberikan pada perlakuan lainnya yakni protein 24$30 \%$, lemak 3-3,3\%, BETN 50,25\%, serat kasar $9,1 \%$, abu $10,5 \%$, fosfor $0,5-$ 0,9\%, kalsium 0,4-1,0\% (Lumpkin and Plucknet, 1982 dalam Handajani, 2007). Jika dibandingkan dengan perlakuan A (rumput gajah) dengan kandungan nutrisi yang terkandung di dalamnya, terdiri dari kandungan air 89\%, abu 2\%, protein kasar 2,97\%, serat kasar 1,63\%, karbohidrat 3,4\%, lemak 1\% (Okaraonye dan Ikewuchi, 2009), pada perlakuan B dengan pakan eceng gondok dengan komposisi kandungan air 90,7\%, abu 2\%, protein kasar $0,9 \%$, serat kasar 2,2\%, karbohidrat 3,9\% dan kandungan lemak 0,4\% (Agrupis, 1953 dalam FAO, 1979), sedangkan kandungan nutrisi pada perlakuan D dengan penggunaan hijauan $P$. Stratiotes, terdiri dari kandungan air 
94,1\% dan protein kasar 0,78\% (Boyd, 1969 dalam FAO, 1979).

Dari data hasil penelitian serta literatur mengenai kandungan nutrisi yang terkandung dalam pakan hijauan tersebut, dilihat bahwa kandungan protein tertinggi pada pakan hijauan tersebut, dapat mempengaruhi laju pertumbuhan ikan koan. Dalam hal ini, protein memiliki peran penting dalam menunjang proses pertumbuhan ikan. Namun pertumbuhan ikan juga dapat dipengaruhi oleh kandungan nutrisi lain, selain protein yakni karbohidrat, serat serta unsur lain yang terdapat dalam pakan tersebut. Disamping itu juga, diduga bahwa rasa dan aroma dari pakan hijauan yang kurang disukai oleh ikan, dalam arti selera makan ikan juga dapat mengurangi nafsu makan dari ikan tersebut sehingga menyebabkan pertumbuhan yang dihasilkan sangat rendah.

Parameter kualitas air pada wadah penelitian menyatakan bahwa kelangsungan hidup ikan koan dalam wadah pemeliharaan selama berlangsungnya proses penelitian, relatif sama dari hari kehari. Keadaan suhu pada kolam tersebut berkisar antara 25,5 $28,5^{\circ} \mathrm{C}$, sedangkan untuk $\mathrm{pH}$ berkisar antara 7,25 - 7,67. Kisaran ini dapat ditoleril oleh ikan koan. Karena ikan koan dapat bertahan hidup pada kisaran suhu air $0-33^{0} \mathrm{C}$ (Frederenko and Fraser, 1978 dalam Cudmore and Mandrak, 2004), sedangkan untuk kisaran $\mathrm{pH}$ antara 5,0 - 9,0 (Shireman dan Smith, 1983 dalam Cudmore dan Mandrak, 2004). Dari hasil penelitian tersebut, menunjukkan bahwa jumlah maupun jenis pakan yang diberikan sudah cukup untuk mendukung kebutuhan pokok ikan bahkan dapat memberikan pertumbuhan. Keadaan ini didukung pula oleh kualitas media air yang cukup menunjang untuk kehidupan ikan. Pakan hijauan azolla ini dapat dikatakan memenuhi syarat untuk dijadikan alternatif pakan ikan koan, baik diberikan secara langsung ataupun diolah dengan campuran beberapa bahan penyusun pakan yang lain, karena berdasarkan hasil wawancara di BBAT Tatelu, menyatakan bahwa komposisi pellet yang biasa diberikan pada ikan koan, yakni pellet bintang 882 untuk ukuran benih, berkisar antara 28 - $30 \%$ kandungan protein, lemak 6,8 \% dan serat mencapai 2,1\%.

\section{KESIMPULAN}

Laju pertumbuhan panjang, pertumbuhan mutlak dan pertumbuhan nisbi dengan nilai terbaik terlihat pada perlakuan $\mathrm{C}$ dengan pakan azolla, kemudian diikuti oleh perlakuan B dengan pakan eceng gondok, perlakuan A dengan pakan rumput gajah dan perlakuan D dengan pakan Kiapu.

\section{DAFTAR PUSTAKA}

Cudmore B, Mandrak NE. 2004. Biological Synopsis of Grass Carp (Stenopharyngodon idella). Canadian Manuscript Report of Fisheries and Aquatic Sciences 2705. Burlington-Kanada.

Effendie M.I. 1978. Biologi PerikananBagian I. Institut Pertanian Bogor. Fakultas Perikanan. Bogor.

FAO. 1979. Buku Pegangan Pemanfaatan

Tanaman Air. Departeman

Perikanan dan Budidaya. http://www.fao.org/DOCREP/003/ X6862E/X6862E03.html. 29/01/2012. 18:01. p.m. 
Haetami K, Kiki., Junianto, Andriani Y. 2005. Tingkat Penggunaan Gulma Air Azolla pinnata Dalam Ransum Terhadap Pertumbuhan dan Konversi Pakan Ikan Bawal Air Tawar. Fakultas Pertanian Universitas Padjajaran. Bandung.

Handajani H. 2007. Peningkatan Nilai Nutrisi Tepung Azolla Melalui Fermentasi. Naskah Publikasi; Fakultas Peternakan Perikanan Universitas Muhammadiyah. Malang.

Kordi H. 2009. Budidaya Perairan. PT Citra Aditya Bakti. Bandung.

Kumean RW. 1997. Pengaruh Pemberian Pakan Bertepung Lamun (Enhalus acoroides) Terhadap Pertumbuhan Ikan Nila Merah (Oreochromis sp). Rencana Kerja Penelitian. Fakultas Perikanan UNSRAT. Manado. 11 hal.

Okaraonye C, Ikewuchi JC. 2009. Nutritional and Antinutritional Components of Pennistum purpureum (Schumach). Dep. of Biochemistry Fac. Sci, University of Port Harcourt. Port HarcourtNigeria. Pakistan Journal of Nutrition 8 (1): 32-34.
Perius, Yulfi. 2011. Nutrisi Ikan. http://yulfiperius.files.wordpress.co m/2011/07/1-pendahuluan.pdf. 28/04/2011. 09:11. a.m.

Rahmaningsih DH. 2006. Kajian Penggunaan Eceng Gondok (Eichornia crassipes) Pada Penurunan Senyawa Nitrogen Efluen Pengolahan Limbah Cair PT. Capsugel Indonesia. Fakultas Teknologi Pertanian Institut Pertanian Bogor. Bogor.

Rizal S. 2010. Pemanfaatan Tambak Untuk Uji Coba Pemeliharaan Kerang Kepah Polimesoda Erosa (Solander, 1786) di Delta Mahakam Provinsi Kalimantan Timur. Hasil Penelitian-Universitas Diponegoro. Semarang. 